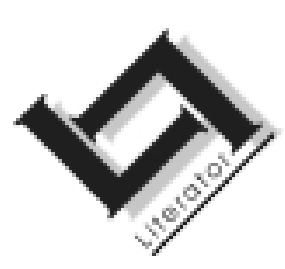

\title{
The Beowulf manuscript reconsidered: Reading Beowulf in late Anglo-Saxon England
}

\author{
Leonie Viljoen \\ Department of English \\ School of Languages \& Literature \\ University of South Africa \\ PRETORIA \\ E-mail: viljol@unisa.ac.za
}

\begin{abstract}
The Beowulf manuscript reconsidered: Reading Beowulf in late AngloSaxon England
\end{abstract}

This article defines a hypothetical late Anglo-Saxon audience: a multi-layered Christian community with competing ideologies, dialects and mythologies. It discusses how that audience might have received the Anglo-Saxon poem Beowulf.

The immediate textual context of the poem constitutes an intertextual microcosm for Beowulf. The five texts in the codex provide interesting clues to the common concerns, conflicts and interests of its audience. The organizing principle for the grouping of this disparate mixture of Christian and secular texts with Beowulf was not a sense of canonicity or the collating of monuments with an aesthetic autonomy from cultural conditions or social production. They were part of the so-called "popular culture" and provide one key to the "meanings" that interested the late Anglo-Saxon audience, who would delight in the poet's alliteration, rhythms, word-play, irony and understatement, descriptions, aphorisms and evocation of loss and transience. The poem provided cultural, historical and spiritual data and evoked a debate about pertinent moral issues. The monsters, for instance, are symbolic of problems of identity construction and establish a polarity between "us" and the "Other"', but at the same time question such binary thinking. Finally, the poem works towards an audience identity whose values emerge from the struggle within the poem and therefore also encompass the monstrous, the potentially disruptive, the darkness within that which the poem attempts to repress. 


\section{Opsomming}

Die Beowulf-manuskrip in heroorweging geneem: die moontlike resepsie van Beowulf in die laat Anglo-Saksiese Engeland

Hierdie artikel defineer 'n hipotetiese laat Anglo-Saksiese gehoor, naamlik 'n veelvlakkige Christelike gemeenskap met wedywerende ideologieë, dialekte en mitologieë. Ook word gespekuleer oor hierdie Anglo-Saksiese gehoor se moontlike resepsie van die gedig Beowulf.

Die onmiddellike tekstuele konteks van die gedig bepaal 'n intertekstuele mikrokosmos vir Beowulf. Die vyf tekste van die kodeks lewer interessante leidrade vir die gemeenskaplike temas, konflikte en belange van die hipotetiese gehoor. Die grondbeginsel vir die groepering van hierdie uiteenlopende mengsel van Christelike en sekulêre tekste rondom Beowulf was nie 'n bepaalde kanon of 'n versameling esteties onafhanklike monumente wat onaangeraak was deur kulturele omstandighede of sosiale produksie nie. Die tekste was deel van die sogenaamde populêre kultuur en verskaf 'n sleutel tot die "betekenisse" waarin die laat Anglo-Saksiese gehoor sou belanggestel het. Hulle sou genot gevind het in die digter se alliterasies, ritmes, woordspel, ironieë, beskrywings, aforismes, en die atmosfeer van verlies en verganklikheid wat geskep word. Die gedig het kulturele, historiese en geestelike inligting verskaf en debat oor pertinente morele temas ontlok. Die monsters is byvoorbeeld simbolies van probleme met identiteitskonstruksie en bewerkstellig 'n polariteit tussen "ons" en die "Ander", maar terselfdertyd bevraagteken hulle sodanige binêre denke. Uiteindelik beweeg die gedig nader aan 'n gehoor-identiteit waarvan die waardes voortvloei uit die stryd in die gedig en wat gevolglik ook die monsteragtige, die potensieel ontwrigtende, die duisternis in die binneste, omvat - dít wat die gedig probeer onderdruk.

There is no reading of a work that is not also a reinterpretation, a "rewriting"; an audience always interprets a literary work in the light of its own concerns (Eagleton, 1983:8). As medievalists in the twenty-first century, we read Beowulf from a post-modern perspective, each from our own place on the continuum of discourse about the meaning and value of literature. This article postulates that a late Anglo-Saxon audience would have done the same from theirs.

\section{The hypothetical late Anglo-Saxon audience (ca 1000-1016)}

This audience would represent a multi-layered community of readers and listeners: the aristocracy and clerics, educated in Mediterranean and Classical Latin, but surely also ordinary people of the lower classes; all of them steeped in their vernacular Germanic-Scandinavian and AngloSaxon oral stories. They would also have read or listened to written literary works, both original and/or in translation. The degree of their 
vernacular literacy was unequalled in Europe at this time and it is plausible to assume that this Old English textual culture contributed to the development of the common values and purpose of nationhood (Niles, 1998:145; Olsen, 1998:353). They were Christians, drawing on the Judaeo-Christian, Latin-Mediterranean and Anglo-Saxon literary and intellectual heritage.

Coming, in all likelihood, from historically diverse cultural and linguistic communities, "composed of often competing ideologies, dialects and mythologies" (Cohen, 1999:5), they would be part of people who had gradually melded together into a larger national grouping occupying what was known by 1000 as Englaland, but as Cohen asserts, without full assimilation, without cultural and linguistic homogeneity.

This audience would share a history of instability and upheaval, conflict over regional supremacy and, from the end of the eighth century, repeated Viking raids and invasions. This was a threat from outside, causing havoc for most of the ninth century, the "Other", culturally, linguistically, spiritually foreign, and therefore a force to strengthen the national solidarity, cohesion and identity - always in constant flux consolidating, perhaps, those values that reinforce ethnic unity. Ironically, this "Other" soon became assimilated into the geographical and national homeland; by the middle of the ninth century much of eastern England had been settled by Danish immigrants in the Danelaw. During the reign of Æthelred (978-1016), this audience would have experienced a renewed and more formidable threat from Danish armies that would lead to the eventual occupation of the throne by a Danish king, Cnut (1016-1066). Æthelred was an incompetent king and unable to hold the country together against the Viking raids. Archbishop Wulfstan's Sermo Lupi Ad Anglos, generally agreed to have been composed in 1014 (Whitelock, 1976:6; Mitchell, 1995:285), gives a vivid picture of a demoralised society, torn apart by betrayals of trust, recriminations and crimes amidst great anxiety about the future:

Forpam hit is on us eallum swutol and gesene pæt we ær pysan oftor bræcan ponne we bettan and py is pysse peode fela onsæge. Ne dohte hit nu lange inne ne ute, ac wæs here and hunger, bryne and blodgyte on gewelhwylcan ende oft and gelome; and us stalu and cwalu, stric and steorfa, orfcwealm and uncopu, hol and hete and rypera reaflac derede swype pearle, and ungylda swyðe gedrehtan, ... (Whitelock, 1976, lines 53-59).

[For it is clear and evident to all of us that we have previously transgressed more often than we have atoned, and therefore much is assailing this nation. Things have not prospered now for a long time at home or beyond our land but there has been warfare and 
famine, burning and bloodshed in nearly every district time and again, and stealing and slaying, plague and pestilence, murrain and disease, enmity and hate and plundering of robbers have harmed us severely. And excessive levies of tribute have greatly afflicted us ...]

Questions about physical and moral dangers, loyalty, leadership, kingship, good governance and guardianship of national assets would surely be in the public arena in these distressing times, given that $Æ$ thelred had come to the throne amidst suspicion and mistrust and repeatedly had to pay the invading Danes ever larger amounts of tribute money in an atmosphere of deceit, betrayal and treachery. 1

\section{How would this late Anglo-Saxon audience respond to Beowulf?}

One clue to their reception of Beowulf would be what interested them as readers and listeners. I believe that an examination of the immediate textual context of the poem in the Nowell Codex (MS Cotton Vitellius $A$ $X V$ can provide some plausible answers.

\section{The Nowell Codex as a possible key to audience reception}

I propose that in the Nowell Codex, generally dated at around the year 1000 , we have a contemporary intertextual microcosm of works in the vernacular that sufficiently interested an early eleventh-century compiler to combine them in one collection. 2 The copy of Beowulf it contains would have been received and read within this context and, conversely, the five texts in the codex, namely a fragment of the Life of St Christopher; Wonders of the East, Letter of Alexander the Great to Aristotle, Beowulf, and Judith, provide interesting clues to the common concerns, conflicts and interests of its audience.

\subsection{The unity of the Codex}

Two important studies have shown inherent coherence in the manuscript beyond the common matter of monsters. First, there is the paleographical evidence. In his edition, Rypins shows convincingly that the

1 He was betrayed twice, for instance, by ÆElfric, the commander of his fleet (Savage, 1982:136-38).

2 The ongoing debate about the date of composition of Beowulf and about its contemporary audience is not germane to the thrust of this article, which concerns itself with audience reception around the time when the manuscript was made, namely AD 1000. For a useful summary, see Bjork and Niles (1997:13-34). 
three prose texts preceding Beowulf - the Life of St Christopher; Wonders of the East and the Letter of Alexander the Great to Aristotle - are clearly the work of a single scribe. Even more significant, however, is that this scribe's hand is also the hand of the first part of Beowulf. I concur with Rypins's contention that this in itself gives the three prose texts an importance that justifies a re-examination of them. Furthermore, Judith and the second portion of Beowulf are written in the same hand. Thus on paleographical grounds alone the five texts were clearly intended to be integral to the project from its inception (Rypins, 1924:viiixiv), or of interest to the same scriptorium at the same time, even though Kiernan would disagree, dating Judith's addition much later than the others (Kiernan, 1981:127). This is in turn refuted by Lucas, who argues that Quire 14, containing Judith, was an integral part of the manuscript (Lucas, 1990:467). Even if Beowulf had been a separate monograph before it was placed in the Nowell Codex, as Kiernan argues so persuasively, the poem seems to have been part of the codex from very early on. Kiernan says that "the two originally separate codices were combined early in their history, most likely in the scriptorium where they were copied". There can be no doubt that considerable planning went into the compilation of the codex (Lucas, 1990:464). I believe that it represents a collection of texts that reflects the interests of both the compiler and the hypothetical late Anglo-Saxon audience.

\subsection{The texts as "popular culture"}

Why were these particular texts grouped together with Beowulf? Why were they translated from the Latin? What was it about them that was regarded as important enough to make them available to a late AngloSaxon audience? How did the Anglo-Saxon audience receive these five works? In this context, how would this audience have reacted to Beowulf?

Working from an established Arnoldian view of canonicity based on literary value, attempts to show unity of purpose in the manuscript have always zoomed outwards from Beowulf, with especially the prose texts located on the periphery, considered of an embarrassingly low literary standard nowhere near the same profundity of thought and style as Beowulf itself. I submit that the eleventh-century Anglo-Saxon compiler of the Beowulf manuscript had a different project, deliberately bringing together into one gathering this disparate mixture of Christian and secular poetry and prose; his organizing principle something other than the Arnoldian sense of canonicity or the collating of Denkmäler, "monuments or memorials, with an aesthetic autonomy from cultural conditions or social production", which, as Seth Lerer has shown, was 
the project of Tolkien and Wülker (Lerer, 1997:330). With Nicholas Howe I would like to pose the question: "Could it be that the Anglo-Saxons thought the three prose texts comparable to Beowulf as entertainment, or even preferred them?" (Howe, 1997:95).

Of course, we cannot know for certain whether they preferred these texts, but we do know that Alexander's Letter was extremely popular, as evidenced by the large number of manuscripts in which it was preserved (Rypins, 1924:xxxiii). Interest in dog-headed people or cynocephali in general, and in Saint Christopher in particular, seems to have been expressed in Celtic countries throughout the medieval period (Orchard, 1995:15). Wonders of the East appeared in continental manuscripts in many forms; "echoes and reflexes" of it also appeared in other texts (Orchard, 1995:22-23). These prose texts were therefore part of the socalled "popular culture" of human interaction and human interest, and it is in their popular culture that "knowledge of humans and their meanings ... is best located" (Ryan, 1996:202). I would therefore argue that the texts of the Nowell Codex provide one key to the "meanings" that interested the late Anglo-Saxon audience as I have defined it.

\section{Intertextual links}

The texts of the manuscript are part of the intertexts which would have created what Lionarons (1998:4) aptly calls the "horizon of expectations" with which the audience would have approached any new story. Hence they would naturally form part of the intertextual web within which this audience would receive Beowulf. It is probable that even within the hypothetical audience there was never a single, commonly accepted reading or understanding of Beowulf. Even so, the texts surrounding the poem contain motifs, images, themes and concerns which are ultimately developed far more profoundly in the text of Beowulf.

These texts provide some evidence of how the Anglo-Saxons constructed their sense of place, both literal and cultural, from the map of the world, evoking the far-away, fabulous world of the Middle East and India in contrast to their own, Germanic world. As such, they hint, as Edward Said asserts in his study of Orientalism, at a polarity or division: on the one hand, they offer topics "of learning, discovery"; on the other, they are "sites of dreams, images, fantasies, myths, obsessions" (Bhabha, 1996: 41). The Orient, says Said, "had been since antiquity a place of romance, exotic beings, haunting memories and landscapes, remarkable experiences" (Said, 1978:1). The depiction of regions in continental Europe, the Middle East and Asia created a collective notion identifying "us" here at home in Anglo-Saxon England against an expansive, yet cautionary mental geography of all the world out there. "... [I]maginative 
geography and history", says Edward Said, "help the mind to intensify its own sense of itself by dramatizing the distance and difference between what is close to it and what is far away" (Said, 1978:55). The presence of the monsters in this geography would serve to demarcate the boundary beyond which lies the unintelligible foreign yet familiar "Other" and reaffirm the notion of the "Self" in its familiar insular Anglo-Saxon place.

\subsection{Life of St Christopher}

The physical details of the monstrous, dog-headed (cynocephalus) St Christopher are matched also in The Wonders of the East: he is

from the race where people have dog's heads and from the land where folk eat each other. He had the head of a dog, and his locks were exceedingly long, and his eyes shone as brightly as the morning-star, and his teeth were as sharp as boar's tusks. He believed in God in his heart, but he could not speak like a man (14). ${ }^{3}$

The triumph of this grotesque monster-missionary against the dark forces within the pagan King Dagnus, so that the king's eyes are literally and figuratively opened and he is converted, introduces a significant thematic thread that weaves through the five texts and is worked out poetically in Beowulf: the antagonistic worlds of monsters and men, and the merging and mingling between them (Orchard, 1995:18). At the same time, there is a concern with the nature of just leadership, and a dialectic between pagan tradition and Christian concerns, ${ }^{4}$ while the person of St Christopher unites the two. He is called by king Dagnus wyrresta wilddeor, "worst of wild animals" $(70),{ }^{5}$ yet the narrator repeatedly calls him se halga cristoforus, "the holy Christopher", and Dagnus is saved through the geearnunga pæs eadigan cristoforus, "the merit of the blessed Christopher" (76).

This quotation is from Orchard's translation of the Latin text. The first part of the Old English version, which probably contained a similar description of the Saint, does not appear in the fragment in the Nowell Codex.

4 The cynocephali were traditionally associated with paganism and, in crusade literature, with the Saracens. Thus Uebel (1996:268) states:

Like the monstrous race of Cynocephali (dog-headed men) with whom they were often identified, Saracens and their religion symbolized the blurring of ideal boundaries, such as those separating rational man from animal or civilized man from barbarian.

5 Quotations from the three prose texts are from the edition by Rypins (1924) with page numbers in brackets. 


\subsection{The Wonders of the East}

This is an illustrated collection of thirty-two marvels immediately following the fragment of The Life of Saint Christopher in the Beowulf manuscript. It treats similar material as that found in Alexander's Letter. The interest obviously lies in the fabulous and the miraculous. More importantly for this discussion, it reveals the mutual mistrust and even open hostility which exist between the worlds of monsters and men. The marvellous creatures all act contrary to common social norms: they either flee at the first sign of people,

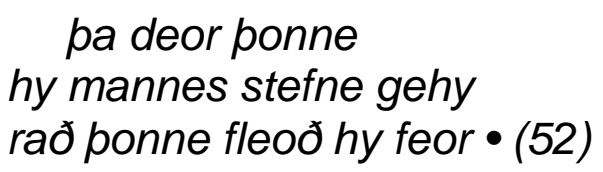

[when the animals hear the voice of men they flee far.]

Gif hy hwilcne man on pæm landum ongytað oððe geseoð ponne fleod hy feor $\cdot(60)$

[If they perceive or see any man in those lands, then they flee far.]

or cause harm to anyone who dares approach, or actively seek men out as prey:

\& hy cunnon mennisce ge

reord ponne hy fremdes cynnes mannan

geseoð ponne nemnað hy hyne \& his magas

cupra manna naman \& mid leaslicum

wordum hy hine beswicað \& hine gefoð \& æfter

pan hy hine fretað ealne buton pon heafde

\& ponne sittað \& wepað ofer pam heafde $\cdot(61-62)$

[and they know human speech. When they see men of a foreign race, they call them and their kinsmen by familiar names and deceive them with false words and seize them and after that they completely devour them except the head and then sit and weep over those heads.]

As is the case in Beowulf, the beasts are mostly presented as a formidable range of foes in the natural world, but this time in distant, exotic locations. The human race is depicted as surrounded and often overpowered by the natural world. In the illustrations accompanying the text of The Wonders of the East in the manuscript (Kiernan, 1999, folios 98b-106b), human vulnerability as opposed to the threat of the monstrous races is made visible: the predominantly over-sized monsters dominate the human figures They push out of their frames, and thus could also signify a threat to well-known human boundaries. The de- 
scription of these wondrous creatures might be considered to represent the pagan and alien, repressed and abjected from the consciousness of this audience. Significantly, dragons are part of this natural world, perhaps even emblematizing it:

Đar beoð dracan cende pa beoð on lenge hundteontiges

fotmæla lange $\bullet \&$ fiftiges hy beod greate

swa stænene sweras micle • for para dra

cena micelnesse ne mæg nan man

na ypelice on pæt land gefaran ... (59)

[There were brought forth dragons that were hundred-and-fifty feet long. They were as great as large stone columns. On account of the greatness of the dragons no man could travel easily in that country.]

The Wonders of the East depicts several human-like creatures similar to the Grendelkin in Beowulf. Their otherness is often stated in terms of their social practices: cannibalism, eating raw fish, giving away women, fleeing from human contact; practices incongruent with those social values cherished by the Anglo-Saxon world, as is evident from the extant literature. Yet there is also a spiritual presence: a temple sacred to the sun, with pæs stillestan bisceopes, "the most gentle bishop" (63).

The theme of the meaning and value of treasure, which is more profoundly developed in Beowulf, is faintly sounded here: in the south of Egypt, we are told, pæm burgum ... beoð eallum worldwelum gyfylled, "the cities are filled with all the worldly wealth" (54). Later, in Alexander's Letter, this theme becomes more prominent, associated with loyalty and friendship, when Alexander looks on King Porus's entire store of treasure and he and his troop are endowed with gold (25).

\subsection{Letter of Alexander the Great to Aristotle}

Viewed in terms of colonial travel writing, describing experiences in exotic locations, Alexander's letter is pure survival literature, as Mary Louise Pratt (1992:20) uses the term; its two great themes being "hardship and danger on the one hand" and "marvels and curiosities on the other". Alexander sets out to describe to his teacher what he experienced on his journey purh monigfeald gewin \& purh micle frecennisse, "through manifold struggles and through great danger" (2). His intention is to relate novelties such as pæm unarimdum cynnum nædrena • \& monna • \& wilddeora, "countless varieties of serpents, and men, and wild beasts" (1). But there is also evidence of his interest in the 
wider universe and the metaphysical: in a previous letter he has written about

pære asprungnisse sunnan \& monan \& be tungla

rynnum \& gesetenissum \& be lyfte tacnugnum $\bullet$ (4)

[the eclipse of the sun and the moon, and the courses of the stars and configurations, and the heavenly signs.]

Alexander continues:

pa đing eall ne magon elcor beon buton $\mathrm{mi}$ celre gemynde swa geendebyrded $\bullet \&$ fore stihtod • (4)

[All these things cannot be otherwise than so arranged and foreordained by a great intelligence.]

Echoes of the creation myth and the power of a prime mover or creator are found also in the last lines of Judith. After the defeat of the invading army and the restoration of order through her victory, honour is given to the lord

\section{pe gesceop wind and lyfte}

roderas and rume grundas, swylce eac reðe streamas

and swegles dreamas purh his sylfes miltse (1047-50). 6

[who created the wind and the clouds, the skies and the spacious plains, and also the raging seas and the joys of heaven through his own mercy]

In Beowulf, the song of creation comes soon after the description of the building of Heorot, an act emblematising King Hrothgar's creation of social order and unity:

frumsceaft fira feorran reccan

Sægde se pe cyðe

cwæð pæt se ÆElmihtiga eorðan worhte

wlitebeorhtne wang, swa wæter bebugeð,

gesette sigehrepig sunnan ond monan

leoman to leohte landbuendum,

ond gefrætwade foldan sceatas

leomum ond leafum, lif eac gesceop

cynna gehwylcnum para de cwice hwyrfap. (90-98)7

6 Quotations from Judith are from Timmer (1952).

$7 \quad$ Unless otherwise stated, all quotations are from Klæber (1941). 
[He who could tell the beginning of men from far back said that the Almighty made the earth, a beautiful plain which water encircles, he triumphantly established the sun and the moon, as light for earthdwellers, and adorned the earth's surfaces with branches and leaves; life also he created in each of those species that live and move.]

In Anglo-Saxon Christian tradition, what Alexander calls micelre gemynde ("greater intelligence") modulates into the belief in God's governance of the world and of every human being, as is evident in both the Life of St Christopher, where the converted king professes:

\section{for pon ic}

nu soðlice wat pæt nan eorðlic anweald ne nan gebrosnodlic nys noht butan his anes \& swa pa wæs geworden purh godes miht ... (75)

[for I now know without doubt that no earthly nor any corruptible power, knows anything outside himself, and so it came to pass through god's power ...]

and in Judith, where her prayer for victory over Holofernes is answered:

Hi ða se hehste Dema

ædre mit elne onbryrde, swa He deठ anra gehwylcne herbuendra, pe Hyne him to helpe seced, mid ræde and mid rihte geleafan (94-97).

[Then the supreme judge forthwith inspired her with courage, just as he does every single dweller on earth who looks to him for help with wisdom and true faith.]

This is one of the cornerstones of the philosophy of Beowulf, binding present and past together in a human history ruled over by an allpowerful God:

\section{Metod eallum weold}

gumena cynnes, swa he nu git deð (1057b-58).

[The lord then ruled the entire race of men just as he still does now.]

As before, in this text human society is defined in terms of its place in the universe and pitted against forces in the natural world where Alexander almost always has to kill the animals he meets in order to proceed with his journey. One description resonates with Beowulf's dragon fight: a night of continuously escalating battles against progressively larger and more frightening specimens of wyrmcyn, the race of serpents (18-21). Alexander's statement that 
Seo eorðe is to wundrienne $\cdot$ hwæt heo ærest oppe godra pinge cenne • oððe eft para yfelra ... (2)

[The earth is a source of wonder first for the good things she brings forth, and then for the evil ...]

is echoed in the social drama of the plot of Beowulf.

Another intertextual thread, which would have woven itself into current debates about good kingship, is the way in which the Old English translator portrays Alexander. The focus is sharply on the king himself, a forceful, proud and mighty leader with a deep appreciation of the loyalty of his men and concern for their well-being. Here I disagree with Andy Orchard's conclusion that the translator intended to expose the arrogance, selfishness and egotism of the Macedonian in "a selfindulgent celebration of personal glory" (Orchard, 1995:135-39). But, as in the world of $Æ$ thelred and Beowulf, Alexander is also not immune to treachery: having offered a reward to pæm us cuplice gelæddon purh pa uncuðan land, "those who led us courteously through that strange land"(18), his men suffer terrible mangling and death in the water. His retribution is swift and grim:

ða wæs ic swiðe irre pæm minum ladpeo wum • pa us on swylce frecennissa gelæd don het hiera da bescufan in pa ea $\cdot 1 \cdot c \cdot$ \& sona pæs de hie inne wæron swa wæron pa nicoras gearwe tobrudon hie swa hie pa oðre ær dydon • (16)

[then I was so angry with my guides who had led us into such peril that I ordered hundred-and-fifty of them to be cast into the river. As soon as they were in, the monsters were ready and tore them apart just as they had done with the others before.]

\subsection{Judith}

In addition to the common concerns I have already referred to, the defeat, in Judith, of an enemy of God by a pious captive as servant of the Saviour, where a Christian leader has taken responsibility for restoring order against an overweening pagan foe, echoes the St Christopher story. The vulnerability of the two protagonists would be abundantly clear to the audience: Judith, wundenlocc, scyppendes mægð, "with braided locks, the Creator's maiden" (77-78), is vividly contrasted in the poem with Holofernes, deofulcunda, galferhð, "diabolical, licentious" (61-62); the saintly Christopher is subjected to unspeakable tortures by fire and crucifixion by the wælgrimma, dysega, "cruel, foolish" (72) King Dagnus. 
Both would be relevant to this audience and to their reading of Beowulf, Judith as an example of how men should defend their country against a powerful invading enemy, and St Christopher defending his faith against deofles willan, "the devil's will" (76).

The poem also introduces the theme of decapitation and dismemberment taken up in Beowulf, a theme which seems to fascinate the AngloSaxon audience (Godfrey, 1993:5) and reveals an interest in the capacity of the head as the seat of intellection and creative and communicative powers. Reading the pious but dumb dog-headed Christopher in this context would present the audience with a tantalizing philosophical puzzle about the cross-over and mingling of the world of monsters and men, the "Other" versus the self.

\section{The reception of Beowulf}

In Beowulf, the audience focus shifts from distant and imaginary worlds 8 to the legendary-mythical-historical world of pagan Scandinavia and, significantly, takes in a Danish line of royal ancestry which intersects, as Niles has shown, "through the figure of Scyld Scefing, with a famously factitious West Saxon royal genealogy" (Niles, 1998:145), 9 thus bringing the events geographically, historically and psychologically closer to home.

If one accepts that these texts, gathered together deliberately in one manuscript, represent common concerns, how would Beowulf serve this audience? Apart from the many links and echoes with the other texts I have already referred to, the events in Beowulf would function educationally and provide the audience with entertainment, with what Greenblatt calls the "experience of wonder", where "the marvellous [is] bound up with the excessive, the surprising, the literally outlandish, the prodigious" (Greenblatt, 1990:339, 348). They would experience the "play-mood" defined by Huizinga (Niles, 1998:149), a mood of "rapture and enthusiasm ... sacred or festive in accordance with the occasion. A feeling of exaltation and tension [would accompany] the action; mirth and relaxation [would] follow." Versed in their own traditional culture, they would delight in the poet's alliteration, rhythms, word-play, irony and

8 This represents what Cohen calls "geographies of the mind", "equivalents of outer space and virtual reality", "never meant to be discovered, always meant to be explored" (Cohen, 1996:18).

9 The names of Scyld, Beow and also Sceaf appear in the later Anglo-Saxon genealogies. 
understatement. His descriptions would captivate them, his evocation of loss and transience would move them, his aphorisms would ring true and give them pause, spurring them to appropriate conduct in times of personal and national adversity.

The text would also provide cultural, historical and spiritual data from their past. As Niles (1998:151) says,

The poet keeps alive the memory of a great number of kings, heroes, and tribes that figure in the storied past of the peoples of the north, thus placing his main character in a larger-than-life setting that constituted a time of origins for the Germanic peoples, one that was analogous to the Old Dispensation under which the Biblical patriarchs lived ... Uniting past and present is an unbroken sequence of providential interventions in human affairs on the part of a divine Will whose design is for our good, however inscrutable it may seem ... Beowulf must have played an educative role in a society whose schools were for the ecclesiastical elite ... Anglo-Saxon heroic poetry offered lessons in life to an aristocracy whose interests were not always served by education through the church.

The poem evokes a debate about moral issues that would have been as pertinent to this audience as to their Germanic-heroic predecessors: the civic values of loyalty, the qualities of leadership/kingship, the relationship between individual, kin and society.

In Beowulf, Grendel and his mother are se pe moras heold, fen ond fæsten, "[those] who held the wasteland, fens and marshes"(103-04). The dragon is se ठe byrnende biorgas seceð/ nacod niðdraca, nihtes fleoged/ fyre befangen; hyne foldbuend/ swiðe ondrædad, "he who, flaming, seeks out burial mounds, the naked evil dragon who flies by night. The land's inhabitants fear him greatly" (2272-75). Here, the monsters are present within the ancestral geography but outside the hall as the centre of community, and would therefore resonate more forcefully than the monsters in foreign, distant lands. Here they would become what Cohen (1999:5) calls "a kind of cultural short-hand for the problems of identity construction" experienced ceaselessly by the Anglo-Saxons.

Monsters, generally, appear in times of crisis, evoking a polarity between "us" and the "Other", but at the same time questioning such binary thinking. 10 Here there is a more profound working out of the paradoxical

10 "And so the monster is dangerous, a form suspended between forms that threatens to smash distinctions ... the monster notoriously appears at times of crisis as a kind of third term that problematizes the clash of extremes - as 'that which questions binary thinking and introduces a crisis'" (Cohen, 1996:6, quoting Marjory Garber). ... "it 
opposition and intermingling of the monstrous and the human that are evoked in the other texts in the codex. They are "at once outside of us and also within us" (Howe, 2000:682). ${ }^{11}$ Cohen uses the Lacanian term extimité, "external intimacy" or "intimate alterity", to capture this conjoining of "absolute otherness with reassuring familiarity" (Cohen, 1999, xiii). His description (Cohen, 1999:26) captures this fundamental concern of the poem very succinctly:

Grendel represents a cultural Other for whom conformity to societal dictates is an impossibility because those dictates are not comprehensible to him; he is at the same time a monsterized version of what a member of that very society can become when those dictates are rejected, when the authority of leaders or mores disintegrates and the subordination of the individual to hierarchy is lost.

The audience is reminded that Heorot is threatened not only from without but also from within. This threat from within resides in the hearts of men, in treachery and strife, in the likes of Heremod and Unferth and in the faithlessness of Beowulf's own warriors. The suggestion of a climate of treachery is first hinted at after the building or Heorot:

Sele hlifade
heah ond horngeap; heaðowylma bad
laðan liges; ne wæs hit lenge pa gen,
pæt se ecghete apumsweoran
æfter wælniðe wæcnan scolde (81-85).

[the hall towered aloft, high and wide-gabled. It awaited the hostile flames, malicious burning; it was not yet the time when the violence between of son-in-law and father-in-law was to break out after deadly enmity.]

This theme is borne out by an examination of the world of Beowulf as a whole. Treachery within tribes is strikingly evident among the Danes. Unferth's treachery appears to be accepted by society. This brotherkiller, pe æt fotum sæt frean Scyldinga, "who sat at the feet of the lord of the Scyldings" (500), has an honoured place in the hall.

breaks apart bifurcating, 'either/or' syllogistic logic with a kind of reasoning closer to 'and/or', introducing what Barbara Johnson has called 'a revolution in the very logic of meaning'" (Cohen, 1996:7).

11 Here we recall also the parallels between hero and monsters made by many critics and also recently on the ANSAX internet discussion forum (Lionarons, Cohen, and recently Benjamin Slade), e.g. also in the use of aglæca. Slade sees Grendel and Beowulf as hall-wards; the dragon and Beowulf as hord-weardas. George Clarke sees Ongentheow paralled with the dragon. 
Here, the leaders of men play out the fundamental myth: like Judith, Christopher and Alexander, Hrothgar and Beowulf oppose such disruptive anti-social forces of chaos, and create or restore cosmic and societal order. Beowulf's victory over Grendel re-establishes the stability of society initially created by Hrothgar in Heorot; mirroring the ideal divine creation. The dragon's attack on Beowulf's stable hall years later similarly signals a destructive incursion from outside against Geatish society. In the end, the death of the dragon, providing a potentially satisfying sense of closure in terms of the well-known dragon-slaying myth, an end by the hero to what Lionarons calls "the ever-escalating cycle of reciprocal violence threatening existence itself" (Lionarons, 1998:8), would be ironically subverted by historical fact, which is poetically embodied in the poignant prophesy of extinction for the Geats:

\section{Geatisc meowle \\ bunden-heorde}

song sorgcearig. Sæde geneahhe, pæt hio hyre here-geongas hearde ondrede, wæl-fylla worn, werudes egesan, hynðo ond hæft-nyd (Wrenn, 1973: lines 3150-55).

[a Geatish woman, with hair bound up, sang a sorrowful song. She said repeatedly that she sorely dreaded evil days, a multitude of slaughters, the terror of warriors, humiliation and captivity.]

In the end, this audience would share in the elegiac tone of nostalgia for the transience and ephemerality of heroic life. Recognising in Beowulf's funeral rites the unresolved tension between pagan and Christian truths, they would lament death but celebrate the achievement of fame by great deeds and rejoice in the qualities of the good king, wyruld-cyninga/ manna mildust ond monðwærust,/leodum liðost ond lofgeornost, "of the kings of this world, the kindest, the most courteous of men, the best to his people, and the most eager for fame" (3180-82). Beowulf's burial mound would "recall and recuperate ... the major formative events of the history of their community" (Connerton, 1989:73).

\section{Beowulf and audience identity}

Finally, the poem would work towards an audience identity whose values would emerge from the struggle within the poem, a struggle which is implicitly and explicitly evident in all the texts of the Nowell Codex. According to Stuart Hall's very striking and useful definition, identity is the fruit of struggle:

Identity is a structured representation which only achieves its positive through the narrow eye of the negative. It has to go through 
the eye of the needle of the other before it can construct itself (Hall, 1991:21).

In the world of the poem, this construct in itself always remains unstable.

Through the eyes of Grendel the audience would see an ordered community delighting in song and laughter and boasting, prizing ceremony, ritual and history, and the values of common loyalty, generosity, reciprocity and kinship. But they would also see a society vulnerable to the threat from what they have abjected outside the borders. 12 The eyes of Grendel's mother would show them the terrible fruits of interminable feud and vengeance. Finally in the eye of the dragon lies the image of a society based on generosity, wise governance and bravery. But, as Rory Ryan (1996:7) reminds us, “... identity as constituted by opposition ... identity relations between [us] and 'other' are already deeply intertwined prior to the assertion of otherness. Mutual invasion has already occurred when otherness is recognised". The identity revealed through the eyes of the monsters would therefore also encompass the monstrous, the potentially disruptive, the darkness within - that which the poem attempts to repress.

\section{Conclusion}

There is ultimately no answer to the question of how this late AngloSaxon audience would have received Beowulf. We cannot escape our own literary, cultural, social, historical and geographical context. We can only speculate. From the available psychological, mythological, historical and poetical data, we can speculate intelligently and perhaps with some measure of accuracy. The Nowell Codex is an early eleventh-century collection of texts of popular culture which gives us a glimpse into the concerns, issues and existential questions occupying the hearts and

It would be good to remember that even if the poem had been created in an earlier historical Anglo-Saxon context, monsters resurface at times of crisis and would do so also for a later audience:

Monsters are our children. They can be pushed to the farthest margins of geography and discourse, hidden away at the edges of the world and in the forbidden recesses of our mind, but they always return. And when they come back, they bring not just a fuller knowledge of our place in history and the history of knowing our place, but they bear selfknowledge, human knowledge - and a discourse all the more sacred as it arises from the Outside. These monsters ask us how we perceive the world, and how we have misrepresented what we have attempted to place. They ask us to reevaluate our assumptions about race, gender, sexuality, our perception of difference, our tolerance towards its expressions. They ask us why we have created them (Cohen, 1996:20) 
minds of the hypothetical contemporary audience. It provides us with one plausible key into that audience's possible reception of Beowulf.

\section{Bibliography}

Bhabha, Homi. 1996. The Other Question. In: Mongia, Padmini (ed.) Contemporary Postcolonial Theory. A Reader. London : Arnold. p. 37-54.

Bjork, Robert E. \& Niles, John D. (eds.) 1997. The Beowulf Handbook. Lincoln : University of Nebraska Press.

Cohen, Jeffrey Jerome (ed.) 1996. Monster Theory: Reading Culture. Minneapolis/ London : University of Minnesota Press.

Cohen, Jeffrey Jerome. 1999. Of Giants. Sex, Monsters, and the Middle Ages. Minneapolis/London : University of Minnesota Press.

Connerton, Paul. 1989. How Societies Remember. Cambridge : Cambridge University Press.

Eagleton, T. 1983. Introduction: What is Literature? In: Literary Theory: An Introduction. Oxford: Blackwell. p. 1-16.

Godfrey, Maria Flavia. 1993. Beowulf and Judith: Thematizing Decapitation in Old English Poetry. Texas Studies in Literature and Language, 35:1-43.

Greenblatt, Stephen. 1990. Resonance and Wonder. In: Collier, Peter \& Geyre-Ryan, Helga (eds.) Literary Theory Today. Cambridge : Polity. p. 74-90.

Hall, Stuart. 1991. The Local and the Global: Globalization and Ethnicity. In: King, A.D. (ed.) Culture, Globalization and the World-System. London : Macmillan. p.19-39.

Howe, Nicholas. 1997. Historicist Approaches. In: O'Keefe, Katherine O'Brien (ed.) Reading Old English Texts. New York, NY/Cambridge, UK : Cambridge University Press. p. 79-100.

Howe, Nicholas. 2000. Review of Cohen, Jeffrey Jerome. Of Giants. Sex, Monsters, and the Middle Ages. Minneapolis/London : University of Minnesota Press. (1999) Speculum, 75:680-82.

Kiernan, Kevin S. 1981. Beowulf and the Beowulf Manuscript. New Brunswick, N.J. : Rutgers University Press.

Kiernan, Kevin S. 1999. Electronic Beowulf. Ann Arbor : University of Michigan Press.

Klæber, Fr. (ed.) 1941. Beowulf and the Fight at Finnsburg. Third Edition, with supplement. Boston : Heath.

Lerer, Seth. 1997. Beowulf and Contemporary Critical Theory. In: Bjork, Robert E. \& Niles, John D. (eds.) The Beowulf Handbook. Lincoln : University of Nebraska Press. p. 325-39.

Lionarons, J.T. 1998. The Medieval Dragon. The Nature of the Beast in Germanic Literature. Enfield Lock : Hisarlik.

Lucas, Peter J. 1990. The Place of Judith in the Beowulf-Manuscript. Review of English Studies, 41:463-78.

Mitchell, Bruce. 1995. An Invitation to Old English and Anglo-Saxon England. Oxford : Blackwell.

Niles, John D. 1998. Reconceiving Beowulf: Poetry as Social Praxis. College English, 61:143-66.

Olsen, Alexandra H. 1998. Beowulf. In: Foley, John Miles (ed.) Teaching Oral Traditions. New York : Modern Language Association of America. p. 351-58. 
Orchard, Andy. 1995. Pride and Prodigies: studies in the monsters of the Beowulf manuscript. Rochester, NY, USA : Brewer [London] : Institute of Germanic Studies.

Pratt, Mary Louise. 1992. Imperial Eyes. Travel Writing and Transculturation. London : Routledge.

Ryan, Rory. 1996. Cultural Studies, Cultural Ethnography and Some Remarks Concerning Human Knowledge. In: Smit, J., Wade, J. \& Van Wyk, J. (eds.) Rethinking South African Literary History. Durban : Y Press. p. 152-76.

Rypins, Stanley (ed.) 1924. Three Old English Prose Texts in MS Cotton Vitellius A $x v$. London : Early English Text Society. Unaltered reprint 1971.

Said, Edward W. 1978. Orientalism. Harmondsworth : Penguin.

Savage, Anne. (trans. and coll.) 1982. The Anglo-Saxon Chronicles. London : Phoebe Phillips/Heinemann.

Timmer, B.J. (ed.) 1952. Judith. London : Methuen.

Uebel, Michael. 1996. Unthinking the Monster: Twelfth-Century Responses to Saracen Alterity. In: Cohen, Jeffrey Jerome (ed.) Monster Theory: Reading Culture. Minneapolis/London : University of Minnesota Press. p. 264-291.

Whitelock, Dorothy (ed. \& rev.) 1976. Sermo Lupi ad Anglos. Exeter : Exeter University Press.

Wrenn, C.L. (ed.) 1973 [1953]. Beowulf, with the Finnesburg Fragment. London : Harrap. Third edition fully revised by W.F. Bolton.

\section{Key concepts:}

Beowulf, audience, reception

civilization, Anglo-Saxon, in literature

epic poetry, English (Old) - history and criticism

literature and society, England, Anglo-Saxon

\section{Kernbegrippe:}

Beowulf, gehoor, resepsie

beskawing, Anglo-Saksies, in die letterkunde

epiese digkuns, Engels (Oud-) - geskiedenis en literatuurstudie

literatuur en samelewing, Engeland, Anglo-Saksies. 
